\title{
Pengaruh Model Pembelajaran Student Teams Achievement Division (STAD) terhadap Kemampuan Pemecahan Masalah Matematika
}

\author{
Effect of Student Teams Achievement Division (STAD) Learning Model on \\ Mathematical Problem Solving Ability
}

\author{
Suriyani \\ Program Studi Pendidikan Matematika, STKIP Labuhan Batu \\ Jalan Sisingamangaraja No. 126A, KM, 3,5 Aek Tapa Rantauprapat email: suryani.jahwa@yahoo.com
}

\begin{abstract}
Abstrak
Penelitian ini bertujuan untuk mengetahui pengaruh model Pembelajaran Student Teams Achievement Division (STAD) terhadap kemampuan pemecahan masalah matematika kelas VIII SMP Muhammadiyah 25 Rantauprapat tahun pembelajaran 2017/2018 dan untuk mengetahui pola jawaban siswa dalam pemecahan masalah matematika. Teknik pengumpulan data diperoleh dengan cara tes berupa soal uraian. Instrument penelitian yang digunakan adalah soal pre-test dan post-test sebanyak 3 soal uraian. Teknik analisis data yang digunakan adalah uji normalitas, uji homogenitas, uji t dengan teknik paired samples t-test. Berdasarkan hasil penelitian, diperoleh nilai rata-rata kelas sebelum perlakuan sebesar 11,79 dan setelah perlakuan menjadi 18,73 , juga terlihat pada pola jawaban siswa sebelum diberikan perlakuan memiliki nilai kategori sedang 24 orang dan kategori rendah 9 orang namun setelah diberi perlakuan memiliki nilai kategori tinggi 12 orang dan sedang 21 orang. Pada hasil uji t diperoleh nilai thitung sebesar 11,601, dan tabel sebesar 2,037, maka 11,601 > 2,037 dengan tingkat signifikan 0,000 $<0,05$ maka $\mathrm{H}_{\mathrm{o}}$ ditolak dan $\mathrm{H}_{\mathrm{a}}$ diterima. Artinya, ada pengaruh model Pembelajaran Student Teams Achievement Division (STAD) terhadap kemampuan pemecahan masalah matematika. Pola jawaban siswa dalam memecahkan masalah matematika pada penyelesaian soal post-test lebih baik daripada penyelesaian soal pre-test. Dimana siswa mampu memahami merencanakan, melaksanakan rencana dan memeriksa kembali jawaban dengan tuntas dan benar.
\end{abstract}

Kata kunci : Pembelajaran Student Teams Achievement Division (STAD), Kemampuan Pemecahan Masalah Matematika

\begin{abstract}
This study aims to determine the effect of Learning Model Student Teams Achievement Division (STAD) on the ability to solve mathematics problems class VIII SMP Muhammadiyah 25 Rantauprapat year of learning 2017/2018 and to know the pattern of student answers in mathematical problem solving. Technique of collecting data obtained by test in the form of description problem. The research instrument used is a matter of pre-test and post-test of 3 questions description. Data analysis techniques used are normality test, homogeneity test, $t$ test with paired samples $t$-test technique. Based on the result of research, we get the average value of class before treatment 11,79 and after treatment become 18,73, also seen in the pattern of answers before the students were given the treatment has a moderate category 24 people and low category 9 people but after being treated has a high category category 12 people and 21 people. In t test results obtained tcount of 11.601, and ttable of 2.037, then 11.601>2.037 with a significant level of $0.000<0.05$ then $\mathrm{Ho}$ is rejected and Ha accepted. That is, there is influence of Learning Model Student Teams Achievement Division (STAD) to the ability of problem solving mathematics. The pattern of students' answers in solving mathematical problems in solving post-test problems is better than solving pre-test problems. Where students are able to understand the plan, execute the plan and re-examine the answers thoroughly and correctly.
\end{abstract}

Key Words : Learning of Student Teams Achievement Division (STAD), Mathematical Problem Solving Ability 


\section{Pendahuluan}

Pemecahan masalah merupakan salah satu kompetensi yang menjadi fokus pembelajaran matematika[1]. Untuk dapat menyelesaikan masalah matematika tersebut maka siswa harus memiliki kemampuan dalam menyelesaikan masalah. Kemampuan menyelesaikan masalah adalah kemampuan siswa dalam mencari cara atau solusi yang tepat untuk menyelesaikan suatu masalah. menjelaskan bahwa pemecahan masalah merupakan suatu proses menerapkan pengetahuan yang diperoleh sebelumnya pada situasi baru dan berbeda. Selain itu, NCTM juga mengungkapkan tujuan pengajaran pemecahan masalah secara umum adalah untuk (1) membangun pengetahuan baru, (2) memecahkan masalah yang muncul dalam matematika dan dalam konteks lainnya, (3) menerapkan dan menyesuaikan bermacam strategi yang sesuai untuk memecahkan masalah, dan (4) memantau dan merefleksikan proses dari pemecahan masalah matematika.

Metode pemecahan masalah adalah suatu cara pembelajaran dengan menghadapkan siswa kepada suatu masalah untuk dipecahkan atau diselesaikan. Pemecahan masalah sangatlah penting dalam belajar matematika [2] mengatakan bahwa pemecahan masalah merupakan kegiatan yang penting dalam pelajaran matematika, karena kemampuan pemecahan masalah yang diperoleh dalam suatu pelajaran matematika pada umumnya dapat ditransfer untuk digunakan dalam memecahkan masalah lain. Kemampuan siswa dalam pemecahan masalah, sangat tergantung kepada guru sebagai pembimbing siswa dalam bertindak sebagai motivator dan fasilitator.

Pemecahan masalah dipandang sebagai suatu proses untuk menemukan kombinasi dari sejumlah aturan yang dapat diterapkan dalam upaya mengatasi situasi yang baru[3]. Pemecahan masalah tidak sekedar sebagai bentuk kemampuan aturan-aturan yang telah dikuasai melalui kegiatan-kegiatan belajar terdahulu, melainkan lebih dari itu, merupakan proses untuk mendapatkan aturan pada tingkat yang lebih tinggi.

Menurut para ahli TIMSS, Martin et. al., PISA dan Nasution[4][5] bahwa hasil penelitian TIMSS tahun 2007 mengatakan bahwa Indonesia menempati peringkat ke 36 dari 48 negara dalam matematika. Aspek yang dinilai dalam matematika adalah pengetahuan tentang fakta, prosedur, konsep, penerapan pengetahuan dan pemahaman konsep Martin et. al., Sementara itu, hasil tes PISA tahun 2006 tentang matematika, siswa Indonesia berada pada peringkat 52 dari 57 negara. Aspek yang dinilai dalam PISA adalah kemampuan pemecahan masalah (problem solving), kemampuan penalaran (reasoning), dan kemampuan komunikasi (communication) (PISA).

Hasil TIMSS dan PISA di atas dapat dijadikan sebagai informasi bahwa masih banyak siswa yang tidak dapat menjawab dengan benar materi ujian matematika yang berstandar internasional. Tidak dapat menyelesaikan soal dengan benar mengindikasikan ada sesuatu yang salah dan belum optimal dalam pembelajaran matematika di sekolah.

Berdasarkan hal di atas salah satu aspek yang dinilai dalam PISA adalah kemampuan pemecahan masalah. Menurut Nasution pemecahan masalah dapat dipandang sebagai proses siswa menemukan kombinasi aturan-aturan yang dipelajarinya lebih dahulu yang digunakan untuk menyelesaikan masalah yang baru. Siswa yang terlatih dengan pemecahan masalah akan terampil menyeleksi informasi yang relevan, kemudian menganalisisnya dan akhirnya meneliti hasilnya. Agar siswa memiliki kemampuan pemecahan masalah yang baik, maka diperlukan kemampuan pemahaman matematis yang bermakna bagi setiap siswa.

Berdasarkan hasil wawancara yang dilakuakan penulis dengan guru mata pelajaran matematika gejala yang ditemukan di SMP Muhammadiyah 25 Rantauprapat banyak siswa yang merasa bosan dan tidak tertarik terhadap pembelajaran matematika, guru mengajar metode ceramah dan tanya jawab namun siswa kurang aktif bertanya karena kurang memahami materi dan masih beranggapan pelajaran matematika itu susah dan tidak menarik. Maka pembelajaran yang tidak menarik bagi siswa sangat berpengaruh terhadap perhatian siswa kepada materi yang disampaikan oleh guru. Akibatnya siswa merasa bosan dan kurangnya perhatian terhadap penjelasan guru hingga siswa ribut didalam kelas dan berdampak pada penguasaan materi siswa tidak maksimal dan ketika dilakukan tes, kuis, atau ujian maka siswa sulit mencapai hasil terbaiknya. Nilai pelajaran matematika peserta didik masih tergolong rendah jika dibandingkan dengan mata pelajaran lainnya. Bukti- bukti empiris dilapangan menunjukkan bahwa kemampuan siswa dalam memecahkan suatu masalah matematika masih rendah hal ini diketahui dari hasil kemampuan pemecahan masalah pada soal cerita dimana pola jawaban siswa tidak memenuhi indikator pemecahan masalah akibatnya hasil pemecahan masalah siswa masih menunjukkan skor yang sebagian besar masih tergolong rendah atau kurang.

Berdasarkan pengamatan penulis, kegiatan pembelajaran selama ini masih sebagian besar berpusat pada guru. Guru mengaitkan materi dengan kehidupan sehari-hari peserta didik namun sering membuat siswa kebingungan dalam memecahkan suatu permasalahan yang berbeda dari 
yang pernah dicontohkan dari gurunya, guru yang bersangkutan menyatakan bahwa peserta didik dalam pembelajaran matematika masih ada beberapa yang melakukan aktivitas lain didalam pembelajaran misalnya bercerita dengan teman, tidak memperhatikan, mengantuk, dan lainnya.

Dari penjelasan di atas, dibutuhkan solusi yang kiranya dapat mengatasi masalah belajar siswa tersebut. Salah satu solusi yaitu dengan pembelajaran yang menyenangkan. Pembelajaran yang menyenangkan bagi siswa harus diterapkan untuk menarik minat, motivasi, dan perhatian siswa dalam pembelajaran dan sering memberikan latihan soal cerita yang rutin sehingga pembelajaran bisa berjalan dengan baik untuk hasil belajar yang maksimal. Pembelajaran yang seperti ini salah satunya dengan menggunakan model pembelajaran STAD.

Model pembelajaran STAD (Student Teams-Achievement Divisions) merupakan salah satu model pembelajaran kooperatif untuk membangun pembelajaran yang aktif. Dalam STAD siswa dituntut untuk bisa bekerja sama dalam sebuah kelompok, berinteraksi dengan teman sekelas, melatih jiwa kepemimpinan dan organisasi, serta toleransi menghargai perbedaan yang muncul dalam kelompok. Dengan diterapkannya model ini diharapkan bisa menjadikan pembelajaran lebih aktif dan pada akhirnya ialah hasil belajar yang maksimal, untuk menanggulangi permasalahan yang ada. Penulis menyusun rumusan masalah sebagai berikut: Apakah ada Pengaruh Model Pembelajaran Student Teams Achievement Division (STAD) Terhadap Kemampuan Pemecahan Masalah Matematika Kelas VIII SMP Muhammadiyah 25 Rantauprapat Tahun Pembelajaran 2017/2018 dan bagaimanakah pola jawaban siswa dengan Model Pembelajaran Student Teams Achievement Division (STAD) Terhadap Kemampuan Pemecahan Masalah Matematika Kelas VIII SMP Muhammadiyah 25 Rantauprapat Tahun Pembelajaran 2017/2018?

\section{Metode Penelitian}

Penelitian ini menggunakan jenis penelitian Kuantitatif dan metode yang digunakan yaitu metode quasi-eksperiment. Dalam penelitian ini dipandang tepat karena penelitian ini bertujuan untuk memperoleh informasi tentang pengaruh model pembelajaran kooperatif tipe STAD terhadap kemampuan pemecahan masalah matematika. Tempat penelitian ini berada di SMP Muhammadiyah 25 Rantauprapat Kecamatan Rantau Utara, Kabupaten Labuhanbatu. Adapun waktu penelitian dilaksanakan pada tanggal 24 s/d 29 Juli 2017 pada semester I tahun pembelajaran 2017/2018 dengan 4 kali pertemuan setiap pertemuan 2 × 40 menit. Desain penelitian pada tabel berikut ini.

Tabel 1. Desain Penelitian

\begin{tabular}{|c|c|c|c|}
\hline Kelompok & Tes Awal & Perlakuan & Tes Akhir \\
\hline Eksperimen & Pre-test & $\begin{array}{c}\text { Model } \\
\text { STAD }\end{array}$ & Post-test \\
\hline
\end{tabular}

Sampel pada penelitian ini adalah siswa kelas $\mathrm{VIII}{ }^{\mathrm{B}}$ dengan jumlah siswa yaitu 33 siswa. Instrumen yang digunakan dalam penelitian ini adalah tes kemampuan pemecahan masalah matematika sebanyak 3 soal yang digunakan untuk pre-test dan post-test. Analisis untuk pengujian hipotesis menggunakan uji t dengan teknik paired samples t-test, namun sebelum dilakukan uji t terlebih dahulu dilakukan uji normalitas menggunakan uji chi kuadrat dan homogenitas menggunakan uji $\mathrm{F}$.

\section{Hasil Penelitian dan Pembahasan Hasil Penelitian}

Tabel 2. Hasil Pre-Test Kemampuan Pemecahan Masalah Matematika siswa

\begin{tabular}{|c|c|c|}
\hline \multirow{2}{*}{ No. } & \multirow{2}{*}{ Teorema Pythagoras } & Pre-test \\
\cline { 3 - 3 } & & Eksperimen \\
\hline 1 & Mean & 11,79 \\
\hline 2 & Standart Deviasi & 3,752 \\
\hline 3 & Varians & 14,08 \\
\hline 4 & Skor Tertinggi & 16 \\
\hline 5 & Skor Terendah & 2 \\
\hline
\end{tabular}

Berdasarkan tabel diatas hasil pre-test kemampuan pemecahan masalah yaitu nilai tertinggi 16 dan terendah 2 maka dapat dikelompokkan seperti tabel dibawah ini. 
Tabel 3. Hasil Pengelompokkan pre-test

\begin{tabular}{|c|c|c|}
\hline No & Interval & Frekuensi \\
\hline 1 & $21-30$ & - \\
\hline 2 & $11-20$ & 24 \\
\hline 3 & $1-10$ & 9 \\
\hline \multicolumn{2}{|c|}{ Jumlah } & 33 Orang \\
\hline
\end{tabular}

Berdasarkan tabel diatas terlihat bahwa kemampuam pemecahan masalah matematika siswa kelas VIII Muhammadiyah 25 Rantauprapat 9 orang siswa kategori rendah dan 24 orang siswa kategori sedang.

Tabel 4. Hasil Post-Test Kemampuan Pemecahan Masalah Matematika siswa

\begin{tabular}{|c|c|c|}
\hline \multirow{2}{*}{ No. } & Teorema Pythagoras & $\begin{array}{c}\text { Pros-test } \\
\text { Eksperimen }\end{array}$ \\
\hline 1 & Mean & 18,73 \\
\hline 2 & Standart Deviasi & 4,017 \\
\hline 3 & Varians & 16,14 \\
\hline 4 & Skor Tertinggi & 26 \\
\hline 5 & Skor Terendah & 12 \\
\hline
\end{tabular}

Berdasarkan tabel diatas hasil post-test kemampuan pemecahan masalah yaitu nilai tertinggi 26 dan terendah 12 maka dapat dikelompokkan seperti tabel dibawah ini.

Tabel 5. Hasil Hasil Pengelompokkan post - test

\begin{tabular}{|c|c|c|}
\hline No & Interval & Frekuensi \\
\hline 1 & $21-30$ & 12 \\
\hline 2 & $11-20$ & 21 \\
\hline 3 & $1-10$ & - \\
\hline \multicolumn{2}{|c|}{ Jumlah } & 33 Orang \\
\hline
\end{tabular}

Berdasarkan tabel diatas terlihat bahwa kemampuam pemecahan masalah matematika siswa kelas VIIIB Muhammadiyah 25 Rantauprapat 12 orang siswa kategori tinggi dan 21 orang siswa kategori sedang. Sedangkan Perbandingan hasil pre-test dan post-test kemampuan pemecahan masalah matematika siswa kelas VIII ${ }^{\mathrm{B}}$ SMP Muhammadiyah 25 antauprapat dapat dilihat pada tabel 6 berikut ini :

Tabel 6. Perbandingan Hasil Pretest dan Posttest Kemampuan Pemecahan Masalah Matematika Siswa

\begin{tabular}{|c|c|c|c|c|}
\hline \multirow{2}{*}{ No. } & \multirow{2}{*}{ Kategori } & \multirow{2}{*}{$\begin{array}{l}\text { Interval } \\
\text { Nilai }\end{array}$} & \multicolumn{2}{|c|}{ Frekuensi } \\
\cline { 3 - 5 } & & Pretest & Posttest \\
\hline 1 & Tinggi & $21-30$ & - & 12 \\
\hline 2 & Sedang & $11-20$ & 24 & 21 \\
\hline 3 & Rendah & $1-10$ & 9 & - \\
\hline \multicolumn{3}{|c|}{ Jumlah } & 33 siswa & 33 siswa \\
\hline
\end{tabular}

Dari tabel perbandingan diatas, dapat dilihat adanya perubahan antara frekuensi pre-test dan post-test. Lebih jelasnya lihat diagram batang perbandingan hasil pre-test dan post-test dibawah ini :

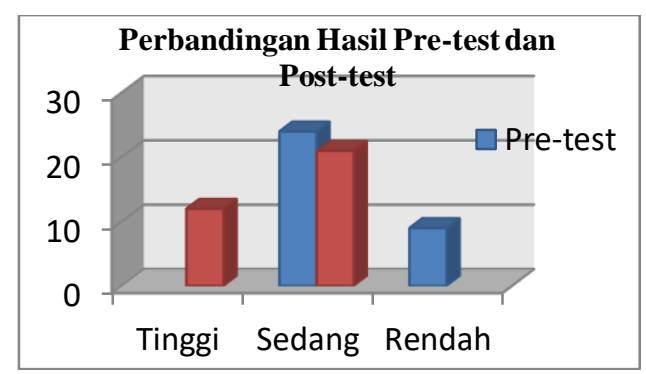

Gambar 1. Perbandingan Hasil Pre-test dan Post-test 
Berdasarkan hasil pekerjaan siswa pada soal post-test diatas, terlihat bahwa siswa mampu menuliskan yang diketahui dan ditanyakan dengan menggunakan kata-kata sederhana pada soal dan membuat sketsa gambar. Oleh karena itu, siswa dikatakan mampu memahami masalah. Setelah memahami selanjutnya siswa merencanakan penyelesaian terlihat siswa hanya mampu menuliskan rumus saja tidak menuliskan nilai-nilai yang terdapat pada rumus tersebut, selanjutnya melaksanakan rencana disini siswa mampu menyelesaikan soal dengan baik dan benar setelah itu siswa melakukan pemeriksaan kembail jawaban dalam hal ini siswa juga mampu melakukan pemeriksaan soal dengan benar. Dari pola jawaban siswa diatas, terlihat bahwa setelah diberikan perlakuan (treatment) pola jawaban siswa rata-rata mampu memahami menuliskan rumus dan menyelesaiakan soal dengan tuntas. pada soal post-test banyak siswa yang menjawab dengan hasil benar dan tuntas, namun rata rata siswa dalam tahap merencanakan hanya mampu menuliskan rumus saja dan masih ada beberapa orang siswa yang menjawab salah.

Berdasarkan perhitungan uji normalitas dimana nilai sig > 0,05 yaitu 0,685 > 0,05 yang berarti bahwa data berdistribusi normal. Berdasarkan perhitungan uji homogenitas dimana sig $>0,05$ yaitu 0,549 $>0,05$ yang berarti bahwa data homogen.

Hasil Uji Hipotesis Paired Samples T-Test Data Pre-test dan Post-test kelas eksperimen dengan cara SPSS diperoleh nilai sig $<$ taraf signifikansi yaitu $0,000<0,05$ dengan nilai $\mathrm{t}$ hitung $>\mathrm{t}$ tabel yaitu $11,601>2,037$ maka disimpulkan $\mathrm{Ho}$ ditolak dan $\mathrm{H}_{\mathrm{a}}$ diterima yang berarti terdapat perbedaan yang signifikan kemampuan pemecahan masalah matematika siswa kelas VIII ${ }^{\mathrm{B}}$ SMP Muhammadiyah 25 Rantauprapat tahun pembelajaran $2017 / 2018$ setelah diberikan perlakuan.

\section{Pembahasan Penelitian}

Berdasarkan penelitian dan pembahasan data menunjukkan bahwa rata-rata hasil tes kemampuan pemecahan masalah matematika siswa kelas VIII ${ }^{\mathrm{B}}$ SMP Muhammadiyah 25 Rantauprapat tahun pembelajaran 2017/2018 yang diajarkan menggunakan model pembelajaran kooperatif tipe STAD sebelum perlakuan siswa diberi pre-test untuk mengetahui kemampuan awal dan stelah perlakuan siswa diberi Post- test dalam mempelajari matematika. Soal pre-test dan Post-test terdiri dari 3 butir soal tentang Teorema Pythagoras, soal ini diberikan untuk siswa kelas eksperimen. Berdasarkan hasil pengolahan data yang telah diuraikan sebelumnya, skor sebelum diberi perlakuan dan skor setelah diberi perlakuan terdapat perbedaan. Hal ini terlihat dari hasil pengujian hipotesis dengan uji Paired Samples TTest untuk sampel yang berdistribusi normal diperoleh nilai Sig. (2-tailed) sebesar 0,000 dan nilai Sig. (2tailed) $<0,05$ dengan nilai t hitung $>\mathrm{t}$ tabel yaitu 11,601 > 2,037 maka $\mathrm{H}_{0}$ ditolak dan $\mathrm{H}_{\mathrm{a}}$ diterima dengan kata lain terdapat pengaruh model pembelajaran Student Teams Achivement Division (STAD) terhadap kemampuan pemecahan masalah matematika pada materi Teorma Pythagoras.

Selain dilihat dari uji hipotesis, pengaruh kemampuan pemecahan masalah matematika siswa juga dapat dilihat dari skor yang diperoleh siswa dari pola jawaban siswa dimana siswa akan dinilai dengan beberapa indikator yaitu memahami masalah, merencanakan, melaksanakan rencana dan memeriksa kembali jawaban. Terlihat pada pola jawaban siswa setelah diberi perlakuan siswa mampu memahami masalah menuliskan rumus namun tidak menuliskan nilai-nilai yang terdapat pada rumus mungkin siswa hanya mampu pada tahap penulisan rumus saja dalam melaksanakan rencana rata-rata siswa mampu menyelesaikannya dengan baik dan pada tahap pemeriksaan kembali siswa juga mampu memeriksa kembali jawaban dengan tuntas.

Berdasarkan hasil penskoran indikator pemecahan masalah berdasarkan 3 kategori maka pada soal pre-test skor siswa dengan kategori tinggi tidak ada, sedangkan pada soal post-test skor siswa dengan kategori tinggi sebanyak 12 orang. Untuk skor kategori sedang pada soal pre-test sebanyak 24 orang dan pada soal post-test hanya 21 orang serta skor kategori rendah pada soal pre-test sebanyak 9 orang dan pada soal post-test tidak ada. Hal ini maka pola jawaban siswa setelah mendapatkan perlakuan (treatment) lebih baik daripada pola jawaban siswa sebelum mendapatkan perlakuan (treatment). Maka dapat disimpulkan bahwa setelah diberi perlakuan terdapat peningkatan atau dengan kata lain skor posttest lebih tinggi dibandingkan skor pre-test. Berarti model pembelajaran tipe STAD mempengaruhi kemampuan pemecahan masalah matematika siswa. Dengan demikian penelitian "pengaruh model pembelajaran Student Teams Achivement Division (STAD) terhadap kemampuan pemecahan masalah matematika pada materi Teorma Pythagoras" mampu menjawab hipotesis yang diajukan melalui analisis data-data yang diperoleh yaitu penelitian membuktikan bahwa terdapat pengaruh terhadap kemampuan pemecahan masalah matematika siswa.

\section{Kesimpulan}

Terdapat pengaruh penggunaan model Pembelajaran kooperatif tipe STAD terhadap kemampuan pemecahan masalah pada materi Teorema Pythagoras Kelas VIII SMP Muhammadiyah 25 Rantauprapat. Hal ini dapat dibuktikan dari nilai skor yang diperoleh siswa, pada soal pre-test skor siswa dengan kategori tinggi hanya tidak ada, sedangkan pada soal post-test skor siswa dengan kategori tinggi 
sebanyak 12 orang. Untuk skor kategori sedang pada soal pre-test sebanyak 24 orang dan pada soal post-test hanya 21 orang serta skor kategori rendah pada soal pre-test sebanyak 9 orang dan pada soal post-test tidak ada. Demikian juga berdasarkan uji Paired Samples T-Test diperoleh nilai Sig. (2-tailed) sebesar 0,000 dan nilai Sig. (2-tailed) <0,05 dengan nilai t hitung $>$ dari t tabel yaitu 11,601 > 2,037 maka disimpulkan bahwa Ho ditolak dapat diartikan bahwa terdapat pengaruh model pembelajaran STAD terhadap kemampuan pemecahan masalah matematika siswa.maka $\mathrm{H}_{0}$ ditolak dan $\mathrm{H}_{a}$ diterima. Pola jawaban siswa dalam memecahkan masalah matematika pada penyelesaian soal post-test siswa mampu memahami menuliskan rumus dan memeriksa kembali serta menyelesaiakan soal dengan tuntas namun ada beberapa orang yang masih salah dalam tahap merencanakan, siswa hanya mampu menuliskan rumus saja ini berarti pola jawaban siswa setelah perlakuan lebih baik daripada penyelesaian soal sebelum perlakuan. Siswa lebih mampu memecahkan masalah setelah diberi perlakuan (treatment) berupa model pembelajaran tipe STAD.

\section{Daftar Pustaka}

[1] Isnaini, dkk. 2016. Upaya Meningkatkan Kreativitas dan Kemampuan Pemecahan Masalah Matematika Siswa Sekolah Menengah Pertama Melalui Model Pembelajran Treffinger. Banda Aceh: Jurnal Didaktik Matematika

[2] Sutrisno, Joko. 2013. Pemecahan Masalah Sebagai Tujuan dan Proses Dalam Pembelajaran Matematika. Bandar Lampung : Lentera Jurnal Pendidikan.

[3] Hadi, Sutarto dan Radiyatul 2014. Metode Pemecahan Masalah Menurut Polya Untuk Mengembangkan Kemampuan Siswa Dalam Pemecahan Masalah Matematis Di Sekolah Menengah Pertama. Banjarmasin : FKIP Universitas Lambung Mangkurat.

[4] Kesuma, Nila. 2010. Meningkatkan Kemampuan Pemahman Matematis Siswa SMP Melalui Pendekatan Pendidikan Matematika Realistik Indonesia (PMRI). Palembang

[5] Istarani. 2012. 58 Model Pembelajaran Inovatif. Medan : Media Persada 